\title{
APLIKASI SISTEM PAKAR IDENTIFIKASI HAMA DAN PENYAKIT SERTA CARA PENGENDALIANNYA PADA TANAMAN KAKAO BERBASIS ANDROID
}

\author{
${ }^{1}$ Rizki Aptriani, ${ }^{2}$ Didik Kurniawan, ${ }^{3}$ Lestari Wibowo \\ 1,2Jurusan Ilmu Komputer, Fakultas Matematika dan Ilmu Pengetahuan Alam, Universitas Lampung \\ ${ }^{3}$ Jurusan Agroteknologi, Fakultas Pertanian, Universitas Lampung
}

\begin{abstract}
Cocoa (Theobroma cacao L) is one of the plantation commodities that get serious attention because its role is quite high in the national economy. Lampung Province is one of the central cocoa plantations in Indonesia. Cacao cultivation is widely inseparable from a variety of obstacles such as pests and plant diseases. Identification of pests and diseases with various symptoms found in cocoa plants and knowing how to control it is difficult for us, especially farmers in the areas to solve the problem quickly and accurately. Limitations of an expert make handling of pests and diseases of cocoa plants to be difficult, therefore required an expert system that is able to identify pests and diseases in cocoa plants and how to control it based on the knowledge provided by an expert who is able to identify pests and diseases of cocoa and how to control it. This research applied the calculation method of Theorem bayes to calculate the percentage of value. The calculation result is a percentage value and the user can directly see the way pest and disease control are identified. Testing of this research using method Black Box Equivalence Partitioning (EP). Testing questionnaires are divided into 2 variables: user friendly variable and interactive variable. Tests of user friendly variables obtained an average rating of $87.6 \%$ and interactive test variables obtained an average rating of $87.52 \%$. With the test results the system shows this app is feasible to use.
\end{abstract}

Keywords: Pest and disease control of cocoa plants, expert systems, cocoa, Theorema bayes.

\section{PENDAhuluan}

Kakao merupakan salah satu komoditi perkebunan yang mendapatkan perhatian serius karena perannya cukup tinggi dalam perekonomian indonesia. Hal ini terlihat dari luas area tanaman kakao yang cukup tinggi di Indonesia yaitu 1.704 .982 hektar, dengan total produksi 701.229 ton pada 2015. Luas lahan kakao tersebut $87,4 \%$ dikelola oleh rakyat, selebihnya dikelola perkebunan besar negara $(6,0 \%)$ [1] dan perkebunan besar swasta. Budidaya kakao secara luas tidak terlepas dari berbagai hambatan antara lain serangan hama dan penyakit pada tanaman kakao.keterbatasan seorang pakar yang dapat memeberikan informasi tentang serangan hama dan penyakit serta cara pengendaliannya, dapat mengakibatkan penurunan hasil produksi. Kemajuan teknologi dan infomasi saat ini membuat semakin banyak perangkat lunak yang dapat bekerja dalam semua hal seperti seorang pakar.

Sebuah sistem pakar biasanya dibutuhkan metode-metode yang digunakan untuk mendukung berjalannya sistem. Metode kali ini yang membantu dalam pembuatan aplikasi sistem pakar ini adalah 
metode Teorema Bayes. Metode ini mampu menyelesaikan masalah tentang suatu ketidakpastian, rumus perhitungan dari metode ini lebih sederhana dari metode-metode yang lain. Metode Teorema bayes juga biasa digunakan dalam statistika untuk menghitung suatu peluang.

Kajian terdahulu sebagai bahan referensi yaitu penelitian sebelumnya yang dilakukan oleh Wahyuni dan Darma membahas penentuan varietas tanaman kelapa sawit berdasarkan ketebalan tempurung dan daging buah. hasil persentase yang didapatkan pada penelitian ini yaitu dengan tingkat keakuratan $84,333 \%$ dengan 10 kali pengujian yang telah dilakukan [2].

Latar belakang masalah dan penelitian sebelumnya mendasari peranangan dan penelitian dengan judul "Aplikasi Sistem Pakar Identifikasi Hama dan Penyakit serta Cara Pengendaliannya pada Tanaman Kakao Berbasis Android". Aplikasi sistem pakar ini diharapkan mampu memberikan informasi tentang hama dan penyakit yang menyerang kakao dan cara pengendaliannya. Tujuan dari penelitian ini adalah Membangun aplikasi sistem pakar untuk memberikan informasi tentang identifikasi hama dan penyakit serta cara pengendalian hama pada tanaman kakao dengan berbasis Android.

\subsection{Tanaman Kakao}

Tanaman kakao merupakan salah satu tanaman perkebunan yang sangat cocok ditanam di daerah tropis, seperti wilayah Indonesia. Berdasarkan produktivitas dan kebutuhan masyarakat akan kakao, tanaman kakao merupakan tanaman yang memiliki nilai jual tinggi. Biji-biji kakao yang telah mengalami pengolahan dapat dimanfaatkan sebagai campuran dalam makanan.terdapat beberapa hama dan penyakit yang cukup penting dalam tanaman kakao diantaranya.[3]

\section{Kepik Penghisap Buah}

Gejala-gejala yang ditimbulkan yaitu buah muda yang terserang mengering dan rontok, jika tumbuh permukaan kulit buah akan retak, dan terdapat bintik-bintik cokelat kehitaman.

\section{Penggerek Buah Kakao}

Gejala-gejala yang ditimbulkan yaitu buah akan lebih awal berwarna kuning, jika digoyangkan tidak berbunyi, buah akan lebih berat, dan biji-biji saling melekat.

\section{Ulat Api}

Gejala-gejala yang ditimbulkan oleh serangan ulat api antara lain daun berbintik-bintik transparan, daun menguning, daun mengering, dan daun berlubang.

\section{Ulat Kilan}

Gejala-gejala yang ditimbulkan oleh ulat kilan yaitu daun berlubang, pucuk tanaman gundul sehingga tinggal tulang dan daun saja.

\section{Penggerek Batang}

Gejala-gejala yang ditimbulkan oleh serangan penggerek batang adalah batang menjadi layu, batang menjadi kering, dan kemudian batang akan mati

\section{Kumbang Apoginia. sp}

Gejala-gejala yang ditimbulkan oleh serangan kumbang apoginia seperti daun berlubang dan kerusakan yang terjadi pada bagian pinggir daun. 


\section{Tikus}

Gejala-gejala yang ditimbulkan oleh serangan Tikus adalah buah menjadi berlubang, buah menjadi busuk, kerusakan sering terjadi pada buah yang sudah matang.

\section{Vascular Streak Dieback(VSD)}

Gejala-gejala yang ditimbulkan oleh VSD yaitu daun menguning, ranting terlihat tanpa daun (ompong), permukaan kulit ranting menjadi kasar dan belang, jaringan pembuluh kayu yang rusak berupa garis-garis kecil(streak) berwarna kecoklatan.

\section{Busuk Buah}

Gejala-gejala yang ditimbulkan oleh busuk buah yaitu buah nampak bercak-bercak coklat kehitaman, buah menjadi busuk, buah kakao terasa lembek dan basah jika tersentuh jari.

\section{Antraknose}

Gejala-gejala yang ditimbulkan oleh antraknose adalah daun mengering, buah nampang bercakbercak coklat kehitaman, buah menjadi busuk, terdapat bintik-bintik coklat tidak beraturan pada daun, dan buah muda menjadi layu, kering, dan mengeriput.

\section{Jamur Upas}

Gejala-gejala yang ditimbulkan oleh jamur upas yaitu adanya benang-benang jamur tipis seperti sutera pada ranting, terdapat seperti sarang laba-laba, daun banyak yang tetap melekat pada ranting meskipun sudah kering, dan tanaman mati.

\section{Jamur Akar}

Gejala-gejala yang ditimbulkan oleh jamur akar aitu daun mengering, tanaman mati, dan daun kakao menjadi layu.

Hama-hama pada tanaman kakao perlu dikendalikan dengan menerapkan Pengendalian Hama Terpadu (PHT). Penerapan PHT yaitu dengan mengkombinasikan beberapa teknik pengendalian yaitu secara mekanik, hayati, sanitasi, dan kimiawi [4].

\subsection{Sistem Pakar}

Sistem pakar adalah suatu sistem komputer yang mengadopsi kemampuan dari seorang pakar/seorang ahli. Sistem pakar sendiri bertujuan untuk membantu seseorang yang bukan pakar dalam menyelesaikan masalah yang memerlukan hadirnya seorang pakar. Sistem pakar biasanya menangani masalah yang kompleks yang membutuhkan interpretasi pakar dan digunakan untuk menyelesaikan masalah dengan menggunakan komputer dengan model penalaran manusia dan mencapai kesimpulan yang sama dengan dicapai oleh seorang pakar jika berhadapan dengan suatu masalah [5].

\subsection{Teorema Bayes}

Teorema bayes merupakan metode yang digunakan sebagai alat pengambilan keputusan dalam memecahkan suatu masalah ketidakpastian. Metode ini sangat membantu dalam menghitung suatu peluang dengan rumus yang lebih sederhana dari metode lain. Sejumlah teori telah ditemukan untuk menyelesaikan ketidakpastian, salah satu diantaranya adalah probabilitas Bayes (Bayesian 
probalility). Probabilitas menunjukkan kemungkinan sesuatu akan terjadi atau tidak. Hal tersebut disebabkan oleh ketidakmampuan seorang pakar untuk merumuskan kaidah secara pasti.

Metode teorema bayes memiliki kemampuan yang baik dalam hal akurasinya. Metode ini sangat membantu pengembang sistem dalam menghitung nilai probabilitas untuk menentuan peluang suatu kejadian, metode ini juga dimanfaatkan dalam mendukung pengambilan suatu keputusan. Persamaan rumus teorema bayes dituliskan dalam bentuk umum yaitu sebagai berikut. Bentuk umum Theorema Bayes :

$P\left(H_{k} \mid E\right)=\frac{P\left(E \mid H_{k}\right) \times P\left(H_{k}\right)}{\sum_{k=1}^{n} P\left(E \mid H_{k}\right) \times P\left(H_{k}\right)}$

Keterangan:

$\mathrm{P}\left(\mathrm{H}_{\mathrm{k}} \mid \mathrm{E}\right) \quad=$ Probabilitas hipotesa $\mathrm{H}_{\mathrm{k}}$, benar jika diberikan evidence $\mathrm{E}$.

$\mathrm{P}\left(\mathrm{E} \mid \mathrm{H}_{\mathrm{k}}\right) \quad=$ Probabilitas munculnya evidence $\mathrm{E}$ jika diketahui hipotesa $\mathrm{H}_{\mathrm{k}}$ benar.

$\mathrm{P}(\mathrm{Hk}) \quad=$ Probabilitas hipotesa $\mathrm{H}_{\mathrm{k}}$, tanpa memandang evidence apapun.

$n \quad=$ Jumlah Hipotesis yang mungkin.

$k \quad=1 \ldots \ldots \ldots k$

\section{METODE PENELITIAN}

\subsection{Tahapan Penelitian}

Tahapan atau langkah-langkah yang dilakukan pada penelitian ini meliputi study literature, pengumpulan data, perancangan sistem, pembuatan sistem, dan pengujian sistem. Adapun Tahapan penelitian dapat dilihat pada Gambar 3.1

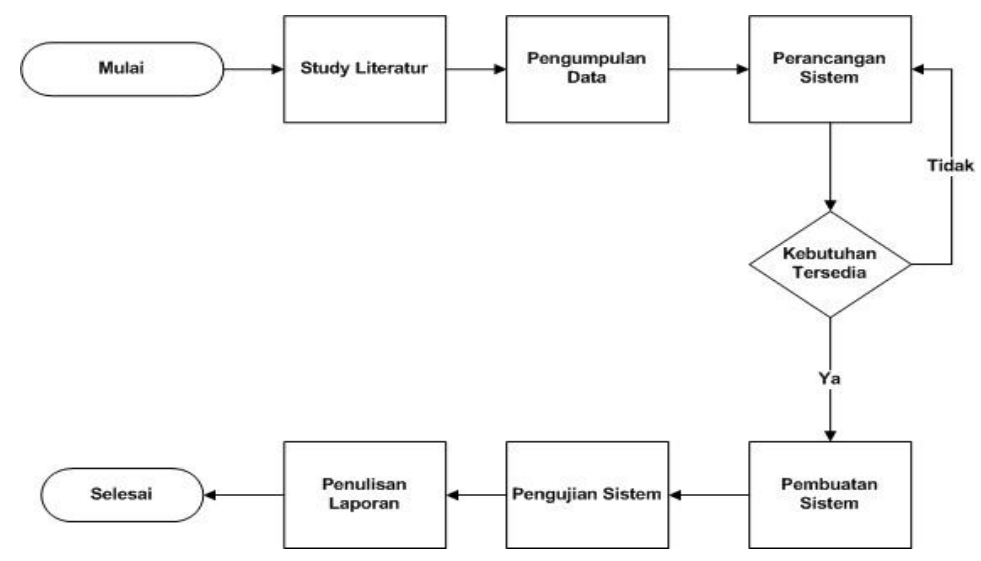

Gambar 1 Tahapan penelitian 


\section{HASIL DAN PEMBAHASAN}

\section{Implementasi Sistem}

Dalam melakukan pengujian dilakukan tiga cara yaitu dengan pengujian sistem, pengujian pakar, dan pengujian kuesioner. Pengujian dilakukan dengan melakukan proses identifikasi pada halaman user interface. User dapat melakukan identifikasi hama dan penyakit dengan cara memilih gejala yang ditampilkan sistem. Berikut adalah tampilan user interface identifikasi hama.

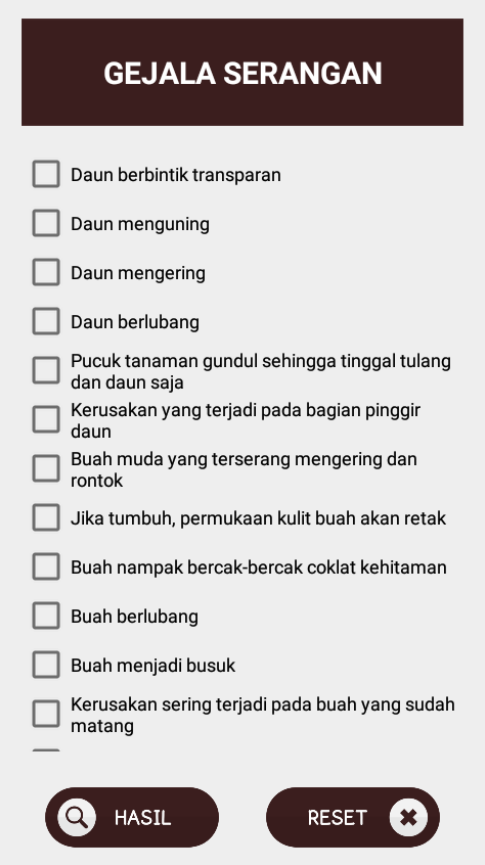

Gambar 2 Halaman identifikasi hama

Setelah user memilih gejala dan menekan button Hasil Identifikasi akan tampil hasil nilai presentase hama penyerang seperti ini. 


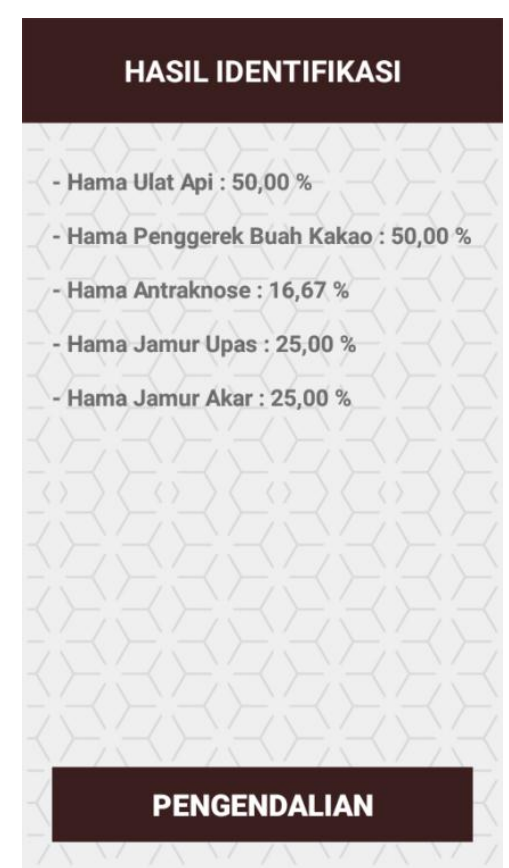

Gambar 3 Halaman hasil presentase hama penyerang

Setelah hasil presentase hama penyerang diperoleh, pengguna dapat melihat cara pengengendaliannya dengan memilih button Pengendalian yang terdapat dibawah hasil nilai presentase.

\section{PENGENdALIAN HAMA ULAT API}

a. Pengendalian Hayati, dengan

Mikroorganisme -Virus Multiple Nucleo

Polyhedrosis virus (MNPV) merupakan

virus yang dapat menginfeksi dan

menyebabkan kematian ulat api. Dosi

yang digunakan adalah $\mathbf{4 0 0}$ gram ulat

yang terinfeksi virus per hektar. Ulat

yang terinfeksi virus per hektar. Ulat

berfirus diblender, disaring dan

diperoleh larutan virus. Larutan virus

murni tersebut kemudian dicampur

dengan 200-250 liter air untuk setiap

hektar. Larutan disemprotkan dengan

menggunakan mist blower.

b. Jika menggunakan lamtoro sebagai

tanaman pelindung, lakukan

pemangkasan ranting-ranting lamtoro

pada waktu ulat masih kecil , kemudian

dimusnahkan

c. Pengendalian Kimiawi, dapat

dilakukan dengan penyemprotan

menggunakan insektisida legaldengan

dosis sesuai dengan yang dianjurkan.

Alat semprot dapat menggunakan

knapsack atau miss blower.

d. Pennendalian Terkini vaitı

Gambar 4 Halaman Cara Pengendalian Hama 
Contoh perhitungan manual

Tabel 1 Data Pengujian

\begin{tabular}{|c|c|c|c|c|c|c|c|c|c|c|c|c|c|c|c|c|c|c|c|c|c|c|c|c|c|c|c|c|c|c|c|c|c|}
\hline \multirow{3}{*}{ No } & \multirow{3}{*}{ Hama/Penyakit } & \multirow{3}{*}{ Nilai Hama } & \multicolumn{31}{|c|}{\begin{tabular}{|c|} 
Nilai Gejala \\
\end{tabular}} \\
\hline & & & G1 & G2 & G3 & G4 & G5 & G6 & G7 & G8 & \begin{tabular}{|l|l|} 
G9 \\
\end{tabular} & G10 & G11 & G12 & G13 & G14 & G15 & G16 & G17 & G18 & G19 & G20 & G21 & G22 & $\mathbf{G 2 3}$ & $\mathbf{G 2 4}$ & G25 & G26 & G27 & G28 & G29 & G30 & G31 \\
\hline & & & 0,1 & 0,2 & 0,3 & 0,3 & 0,3 & 0,1 & 0,2 & 0,2 & 0,4 & 0,5 & 0,5 & 0,3 & 0,3 & 0,4 & 0,5 & 0,2 & 0,3 & 0,3 & 0,4 & \begin{tabular}{|l|}
0,4 \\
\end{tabular} & 0,5 & 0,7 & 0,4 & 0,5 & 0,6 & 0,6 & 0,2 & 0,6 & 0,2 & 0,3 & 0,6 \\
\hline H01 & Ulat Api & 0,3 & \begin{tabular}{|l|l|}
$\checkmark$ \\
\end{tabular} & $\checkmark$ & $\checkmark$ & $\checkmark$ & & & & & & & & & & & & & & & & & & & & & & & & & & & \\
\hline HO2 & Ulat Kilan & 0,3 & & & & $\checkmark$ & $\checkmark$ & & & & & & & & & & & & & & & & & & & & & & & & & & \\
\hline HOS & Kumbang Apoginia & 0,3 & & & & $\checkmark$ & & $\checkmark$ & & & & & & & & & & & & & & & & & & & & & & & & & \\
\hline H04 & Kepik Penghisap & 0,6 & & & & & & & $\checkmark$ & $\checkmark$ & $\checkmark$ & & & & & & & & & & & & & & & & & & & & & & \\
\hline HO5 & \begin{tabular}{|l|} 
Tikus \\
\end{tabular} & 0,5 & & & & & & & & & & $\checkmark$ & $\checkmark$ & $\checkmark$ & $\checkmark$ & & & & & & & & & & & & & & & & & & \\
\hline H06 & Penggerek Buah & 0,5 & & & & & & & & & & & & & $\checkmark$ & $\checkmark$ & $\checkmark$ & $\checkmark$ & $\checkmark$ & & & & & & & & & & & & & & \\
\hline HO7 & Penggerek Batang & 0,7 & & & & & & & & & & & & & & & & & & $\checkmark$ & $\checkmark$ & $\checkmark$ & & & & & & & & & & & \\
\hline HO8 & VSD & 0,6 & & $\checkmark$ & & & & & & & & & & & & & & & & & & & $\checkmark$ & $\checkmark$ & $\checkmark$ & & & & & & & & \\
\hline HO9 & Busuk Buah & 0,6 & & & & & & & & & $\checkmark$ & & $\checkmark$ & & & & & & & & & & & & & $\checkmark$ & & & & & & & \\
\hline H10 & Antraknose & 0,6 & & & $\checkmark$ & & & & & & $\checkmark$ & & $\checkmark$ & & & & & & & & & & & & & & $\checkmark$ & $\checkmark$ & & & & & \\
\hline H11 & Jamur Upas & 0,9 & & & & & & & & & & & & & & & & & & & & & & & & & & & $\checkmark$ & $\checkmark$ & $\checkmark$ & $\checkmark$ & \\
\hline H12 & Jamur Akar & 0,9 & & $\checkmark$ & $\checkmark$ & & & & & & & & & & & & & & & & & & & & & & & & & & & $\checkmark$ & $\checkmark$ \\
\hline
\end{tabular}

Pada sebuah kasus user memilih beberapa dari gejala yaitu G3, G14, G28, G30 Yang dimana

: G3 dimiliki ulat api, antraknose, dan jamur akar

G14 dimiliki penggerek

G28 dimiliki jamur upas

1. Ulat api

G30 dimiliki jamur upas dan jamur akar

Jika probabilitas gejala hama ulat api (H01) adalah 0,3

Perhitungan nilai bayes

$$
\begin{aligned}
& P\left(H_{01} \mid G_{3}\right) \quad=\frac{\left[P\left(G_{3} \mid H_{01}\right) \times P\left(H_{01}\right)\right]}{\left[P\left(G_{3} \mid H_{01}\right) \times P\left(H_{01}\right)+\left[P\left(G_{3} \mid H_{10}\right) \times P\left(H_{10}\right)+\left[P\left(G_{3} \mid H_{12}\right) \times P\left(H_{12}\right)\right.\right.\right.} \\
& P\left(H_{01} \mid G_{3}\right)=\frac{[0,3 \times 0,3]}{[0,3 \times 0,3+0,3 \times 0,6+0,3 \times 0,9]} \\
& P\left(H_{01} \mid G_{3}\right)=\frac{0,09}{0,54} \\
& \quad \text { Total bayes } 1=0,16
\end{aligned}
$$

2. Antraknose

$$
\begin{array}{ll}
P\left(H_{10} \mid G_{3}\right. & =\frac{\left[P\left(G_{3} \mid H_{10}\right) \times P\left(H_{10}\right)\right]}{\left[P\left(G_{3} \mid H_{01}\right) \times P\left(H_{01}\right)+\left[P\left(G_{3} \mid H_{10}\right) \times P\left(H_{10}\right)+\left[P\left(G_{3} \mid H_{12}\right) \times P\left(H_{12}\right)\right.\right.\right.} \\
P\left(H_{10} \mid G_{3}\right) & =\frac{[0,3 \times 0,6]}{[0,3 \times 0,3+0,3 \times 06+0,3 \times 0,9]} \\
P\left(H_{10} \mid G_{3}\right) & =\frac{0,18}{0,54}
\end{array}
$$

Total bayes $2=0,3$

3. Hama jamur akar

$$
\begin{aligned}
P\left(H_{12} \mid G_{3}\right) & =\frac{\left[P\left(G_{3} \mid H_{12}\right) \times P\left(H_{12}\right)\right]}{\left[P\left(G_{3} \mid H_{01}\right) \times P\left(H_{01}\right)+\left[P\left(G_{3} \mid H_{10}\right) \times P\left(H_{10}\right)+\left[P\left(G_{3} \mid H_{12}\right) \times P\left(H_{12}\right)\right.\right.\right.} \\
P\left(H_{12} \mid G_{3}\right) & =\frac{[0,3 \times 0,9]}{[0,3 \times 0,3+0,3 \times 0,6+0,3 \times 0,9]} \\
P\left(H_{12} \mid G_{3}\right) & =\frac{0,27}{0,54} \\
P\left(H_{12} \mid G_{3}\right) & =0,5 \quad\left[P\left(G_{30} \mid H_{12}\right) \times P\left(H_{12}\right)\right] \\
P\left(H_{12} \mid G_{30}\right) & =\frac{[0,3 \times 0,9]}{\left[P\left(G_{30} \mid H_{11}\right) \times P\left(H_{11}\right)+\left[P\left(G_{30} \mid H_{12}\right) \times P\left(H_{12}\right)\right]\right.} \\
P\left(H_{12} \mid G_{30}\right) & =\frac{[0,3 \times 0,9+0,3 \times 0,9]}{[0,57} \\
P\left(H_{12} \mid G_{30}\right) & =\frac{0,27}{0,54}
\end{aligned}
$$


Vol 5 No. 1,2017

@2017 Ilmu Komputer Unila Publishing Network all right reserve

$P\left(H_{12} \mid G_{30}\right) \quad=0,5$

Total bayes $3=0,5+0,5=1$

4. Penggerek batang atau cabang

$P\left(H_{06} \mid G_{14}\right)=\frac{\left[P\left(G_{14} \mid H_{06}\right) \times P\left(H_{06}\right)\right]}{\left[P\left(G_{14} \mid H_{06}\right) \times P\left(H_{06}\right)\right]}$

$P\left(H_{06} \mid G_{14}\right)=\frac{[0,4 \times 0,5]}{[0,4 \times 0,5]}$

$P\left(H_{06} \mid G_{14}\right)=\frac{0,2}{0,2}$

Total bayes $4=1$

5. Jamur upas

$$
\begin{aligned}
& P\left(H_{11} \mid G_{28}\right) \quad=\frac{\left[P\left(G_{28} \mid H_{11}\right) \times P\left(H_{11}\right)\right]}{\left[P\left(G_{28} \mid H_{11}\right) \times P\left(H_{11}\right)\right]} \\
& P\left(H_{11} \mid G_{28}\right) \quad=\frac{[0,6 \times 0,9]}{[0,6 \times 0,9]} \\
& P\left(H_{11} \mid G_{28}\right)=\frac{0,54}{0,54} \\
& P\left(H_{11} \mid G_{28}\right) \quad=1 \\
& P\left(H_{11} \mid G_{30}\right)=\frac{\left[P\left(G_{30} \mid H_{11}\right) \times P\left(H_{11}\right)\right]}{\left[P\left(G_{30} \mid H_{11}\right) \times P\left(H_{11}\right)+\left[P\left(G_{30} \mid H_{12}\right) \times P\left(H_{12}\right)\right]\right.} \\
& P\left(H_{11} \mid G_{30}\right)=\frac{[0,3 \times 0,9]}{[0,3 \times 0,9+0,3 \times 0,9]} \\
& P\left(H_{11} \mid G_{30}\right) \quad=\frac{0,27}{0,54} \\
& P\left(H_{11} \mid G_{30}\right) \quad=0,5
\end{aligned}
$$

Total bayes $5=1+0,5=1,5$

Hasil $=$ Total bayes $1+$ Total bayes $2+$ total bayes $3+$ Total bayes $4+$ Total bayes 5

Hasil $=0,16+0,3+1+1+1,5$

Hasil $=3,96$

Maka perhitungan probabilitas hama dan penyakit adalah :

1. Ulat api

$$
\begin{gathered}
H_{01}=\frac{\text { Total bayes } 1}{\text { Hasil }} \times 100 \% \\
H_{01}=\frac{0,16}{3,96} \times 100 \% \\
H_{01}=4 \%
\end{gathered}
$$

\section{Antraknose}

$$
\begin{aligned}
H_{10} & =\frac{\text { Total bayes } 2}{\text { Hasil }} \times 100 \% \\
H_{10} & =\frac{0,3}{3,96} \times 100 \% \\
H_{10} & =7,57 \%
\end{aligned}
$$

\section{Jamur akar}

$H_{12}=\frac{\text { Total bayes } 3 \text { pertama }}{\text { Hasil }} \times 100 \%$

$H_{12}=\frac{0,5}{3,96} \times 100 \%$ 
Vol 5 No. 1, 2017

(C2017 Ilmu Komputer Unila Publishing Network all right reserve

$H_{12}=12,62 \%$

Jamur akar

$$
\begin{aligned}
& H_{12}=\frac{\text { Total bayes } 3 \text { kedua }}{\text { Hasil }} \times 100 \% \\
& H_{12}=\frac{0,5}{3,96} \times 100 \% \\
& H_{12}=12,62 \%
\end{aligned}
$$

\section{Penggerek batang atau cabang}

$$
\begin{aligned}
& H_{07}=\frac{\text { Total bayes } 4}{\text { Hasil }} \times 100 \% \\
& H_{07}=\frac{1}{3,96} \times 100 \% \\
& H_{07}=25,25 \%
\end{aligned}
$$

\section{Jamur upas}

$$
\begin{aligned}
& H_{11}=\frac{\text { Total bayes } 5 \text { pertama }}{\text { Hasil }} \times 100 \% \\
& H_{11}=\frac{1}{3,96} \times 100 \% \\
& H_{11}=25,25 \%
\end{aligned}
$$

\section{Jamur upas}

$$
\begin{aligned}
& H_{11}=\frac{\text { Total bayes } 5 \text { kedua }}{\text { Hasil }} \times 100 \% \\
& H_{11}=\frac{0,5}{3,96} \times 100 \% \\
& H_{11}=12,62 \%
\end{aligned}
$$

\section{Jadi Total Probabilitas Hama}

$\begin{array}{ll}\text { Ulat api } & =4 \% \\ \text { Antraknose } & =7,57 \% \\ \text { Jamur akar } & =25,24 \% \\ \text { Penggerek } & =25,25 \% \\ \text { Jamur upas } & =37,87 \%\end{array}$

Pengujian Kuesioner yang dilakukan melibatkan 100 responden yang dipilih berdasarkan responden yang terlibat dalam penguna aplikasi. Pengujian dikategorikan menjadi 2 varabel yaitu variabel user friendly dan variabel Interaktif. Berdasarkan hasil kuisioner yang telah dilakukan untuk variabel user friendly dengan perhitungan interval diperoleh nilai rata-rata 87,6\% dengan nilai tersebut maka pada variabel ini masuk dalam kategori "Sangat Baik" dan untuk hasil kuisioner yang telah dilakukan untuk variabel interaktif dengan perhitungan interval diperoleh nilai rata-rata 87,52\% dengan nilai tersebut maka pada variabel ini juga masuk dalam kategori "Sangat Baik". 


\section{KESIMPULAN}

Telah dibangun aplikasi sistem pakar identifikasi hama dan penyakit serta cara pengendaliannya pada tanaman kakao dengan metode teorema bayes berbasis android. Aplikasi ini membantu para petani dalam mengidentifikasi hama yang menyerang tanaman kelapa sawit petani dan memberikan informasi cara pengendaliannya.

\section{DAFTAR PUSTAKA}

[1] Kalshoven, L. (1981). The Pests of Crops in Indonesia. Revised by Van Der Laan. Jakarta: PT Ichtiar Baru.

[2] Wahyuni, L., \& Darma, S. (2015, Februari 15). Implementasi Theorema Bayes dalam Menentukan Varietas Tanaman Kelapa Sawit berdasarkan Ketebalan Tempurung dan Daging Buah. Seminar Nasional Teknologi Informasi dan Multimedia. Jakarta. 43-48.

[3] Pujianto. (2008). Panduan Lengkap Budidaya Kakao. Andi Offset :Yogjakarta. 156 Hal

[4] Direktorat Perlindungan Perkebunan.( 2002). Musuh Alami, Hama dan Penyakit pada Tanaman Kakao. Direktorat Jenderal Bina Produksi Perkebunan,: 1-63.

[5] Siswanto. (2010). Kecerdasan Tiruan. Yogyakarta: Graha Ilmu. 